\title{
THE IMPORTANCE OF DIVERGENCY THINKING IN THE ACTIVITIES OF THE PRIMARY SCHOOL TEACHER
}

\section{Shodiyev R.D.}

Doctor Of Pedagogical Sciences, Professor, Karshi State University, Uzbekistan

Yuldashev J.T.

Teacher Of Primary Education, Karshi State University, Uzbekistan

\section{ABSTRACT}

In the article, the theoretical analysis of the research tests of primary school teachers can achieve high efficiency in modern education and the concept of knowledge thinking and the concept of divergent thinking is given.

KEYWORDS:- Divergent thinking, convergent (linear) thinking, fluency, adaptability, creative approach, independent creation, copyrighted programs, non-standard and authoring programs, successful activities, successful activities.

\section{INTRODUCTION}

Nowadays, the primary school teacher should not only have strong, deep knowledge, but also to develop a variety of thinking, which can be creative, independently creatively address the problems that occur in the educational process.

Typically, the primary school teacher can solve any problem correctly due to convergent (linear) thinking, developing schoolchildren in a way of finding this solution only. Such thinking can be explained by means of a fixed idea. It prevents other people to suffice and accept other people to adequately perceive and accepting their minds. Convergent is divergent thinking, unlike the thinking - this is a diverse thinking, which includes finding many answers to this question.

Over the years, the problem of forming divergent thinking has risen several times in psychological and pedagogical literature. Many foreign scientists, including J.Grubber, S.Mednik, D.Grubber, I.V.bloodg, S.Tlaychev, A.Sh.Shnayder, E.TorrGrances Divergent studied the characteristics of thinking and its development factors, experimental psychological research.

As for the history of the "different thinking", the concept of "divergent thinking" was first included in 1967 by the American psychologist J.Gilford. He has highlighted the differences between convergence and divergence. Different thinking means diversity of solving methods of the problem, and this thinking leads to unexpected conclusions, results. Engiford explains the basis of creative creativity as a common creative potential [1].

In the introduction of a new concept, J.Gilford (derogatory "(derived from Latin," and Dividergo-I signal) came from the term. This 
term is included in scientific warranted by Charles Darvin to explain many types of species of cultivation plants, domesticenal breeds and biological types [2].

After analyzing J.Gilford's works on the topic, the basic qualities of divergent thinking can be highlighted: fluency, flexibility, originality and accuracy. Let us consider each of the selected qualities in detail.

The flux is the ability to express numerous ideas in a certain period of time, where attention is paid to the number of ideas, not their quality.

Flexibility is the ability to invite and promote different ideas. That is, it is ability to adapt to another options.

Originality is the ability to promote new, unexpected ideas, which differs from wellknown, ordinary and clear things.

Clarity is the ability to improve the thoughts or give a completed form [3].

Many scholars equate the concept of "divergent thinking" in their works "creativity" and "creativity". Although these concepts are very close, they are not the same. First of all, creativity and creativity is contributing to the other way of thinking, while more than half of them are insignificant and in general. Therefore, different diversity can be called a kind of thinking type of ownership of creators. Different thinking is a unique skill, lies on the basis of creativity, i.e. the manifestation of a non-standard idea is the foundation of any creative.

There are many approaches to identify the concept of divergent thinking, reflecting the complexity of this psychological event, the complexity of its diagnosis and formation.

Psychologists scientists often call divergent thinking, alternative, optionally, different varieties. Such thinking is associated with an image, serves as a means of creating unique ideas, unique ideas. For example, for example, D.bogoVlensky stressed that divergent thinking is a wide meditation ability is the ability to see other qualities of the object being considered. The essence and purpose of this abilities is that in the original sense it provides going out of the boundaries of the original problem [3].

According to A.M.M. Mammyushkin, the structure of the effective thinking cycle of the effective thinking cycle includes a problem and the construction of the mental task. At the same time, connection that causes the problem is characterized as a peculiarity of creative thinking [4].

The purpose of divergent thinking in the works of G.Gruber, E.Torrance is to develop the interest of research, to choose new forms of activity.

If we come to future primary grades, this goal is expressed in the development of the ability to find many solutions. Different thinking better analysis of the teacher, comparing facts, assumptions and expectations, and creating a classification of the data obtained.

The difference in L.Walance, E.Renzuli, D.Filalson research is considered as a key feature of the person. Different types of questions are of great importance in independence, as there is no answer to this question and we also use thinking here, regardless of learning experience. K.V. Krigazunov also suggests understanding as a key sign of distinguishing contestability. The independence of divergency emphasizes that ideas and conclusions are able to use ideas and use ideas.

J.Gildford, G.Gruber, K.Teillor, E.T.Torrance, N.V. Kuzmina, E.L.Prasolova, VI, Given the results in their works .Slangenine, G.S.Suhobskayaand others can be highlighted from them. The authors describe divergent thinking as a functioning, personal quality, ability. [6].

K.V. Kryazunov determines the following 
features of divergent thinking: integrity and systemic, reflections and assessment, ability to determine their own destiny in the context of florability and productivity [6]. It allows all these features within theoretical and practical directed components.

In general, divergent thinking implies finding the vague but proper solution to the problem, which is involved in all the creative opportunities.

Many teachers have little idea of what the ability of the student is creative. They mainly use methods to increase their experiences and others, clearly fulfill their professional duties.

EV.Bondadrevskaya argues that the teacher in the modern world should be able to independently work, develop copyright programs and methods [7].

The primary school teacher needs various thinking to design and exercise their professional pedagogical activity, to analyze pedagogical activity. Teachers need to understand the essence of various approaches in upbringing and education.

The primary school teacher must be able to:

- to be reflected in their own eyes or on the minds and to correct deficiencies available in their activities;

- Could create critical evaluation of various events in the formogene activity;

- to be able to determine its own direction and other solutions in the situation of the solution of.

- Independent implementation of the knowledge and skills of the skills to a new situation;

- Donal conditions The view and access to new teaching problems;

- Creating alternative options in solving the solution and being able to review the solution in them;

- Can i can member and change methods in solving them;

- Prompting methods and technologies.

Consequently, divergent thinking teachers choose to open and organize the meaning of the educational process.

In every person, different thinking is manifested in every extent, which can be affected.

The first factor is intelligence. According to the definition given in the psychological dictionary, under the mind we mean we show relatively stable, systematic knowledge skills.

It should be noted that the effectiveness of divergent thinking is found at a certain level of mental abilities. Some individuals' levance levels are low and divergent thinking, while others have a high efficiency of intelligence and divergency. However, in the subjects, which are necessary to achieve highnesses of the intellect, in some cases, in some cases, divergent thinking can be low. As a result of our observations, we identified it that the level of minds was founders with the effectiveness of different thinking.

The second factor affects the development of different thinking is a stress resistance. The concept of stress resistance in the psychological dictionary is determined by the combination of personal qualities that allow to cope with stressful situations for human and other creatures. Factors of the environment and reduction of its impact are: forecasting any events, to prepare for them, to manage the process to know them in advance.

\section{Conclusion}

In conclusion, divergent thinking is not only able to find a lot of answers to the same problem, not only one right solution. They are free of 
CURRENT RESEARCH JOURNAL OF PEDAGOGICS 2(7): 19-22, July 2021

DOI: https://doi.org/10.37547/pedagogics-crjp-02-07-05

ISSN 2767-3278

(C)2021 Master Journals

Crossref do) 81 Google

Accepted 24thJuly, 2021 \& Published 29th July, 2021

stereotypes, so they can offer many nonstandard ideas. After analyzing the current situation, they will find the most effective solutions for the problem. Forming divergent thinking is the main condition of the teacher's successful professional activity.

\section{REFERENCES}

1. Гилфорд Дж. Три стороны интеллекта // Психология мышления. М., 1969. С. 433456.

2. Богоявленская Д.Б. Психология творческих способностей. М., 2002.

3. Богоявленская Д.Б., Сусоколова И.А. К вопросу о дивергентном мышлении // Пси-хологическая наука и образование. 2006. № 1. С. 85-96.

4. Матюшкин А.М. Развитие творческой личности. М.: Педагогика, 1991. 180 с.

5. Дружинин В.Н. Психология общих способностей. СПб., 2007.

6. Дрязгунов К.В. Формирование дивергентного мышления учителей в системе по-вышения квалификации: дис. ... канд. пед. наук. Калуга, 2002.

7. Алымова М.Г. Формирование дивергентного мышления у студентов педагогиче-ских специальностей в условиях современного вуза // Вестник Восточно-Сибирской государствен-ной академии образования. 2012. № 17. С. 2023. 